\title{
Phosphate and Potassium Retention and Release during Chrysanthemum Production from Precharged Materials: II. Calcined Clays and Brick Chips
}

\author{
Kimberly A. Williams ${ }^{1}$ and Paul V. Nelson ${ }^{2}$ \\ Department of Horticultural Science, North Carolina State University, Raleigh, NC 27695-7609
}

ADDitional INDEX wORDs. Dendranthema $\times$ grandiflora, soilless substrate, adsorption, attapulgite, arcillite

\begin{abstract}
Soilless container media have almost no capacity to retain $\mathrm{PO}_{4}$ or $\mathrm{K}$. The nutrient retention of two calcined clays, attapulgite and arcillite, and brick chips, precharged with $\mathrm{PO}_{4}$ and $\mathrm{K}$, was investigated. These could serve as an alternative slow-release fertilizer when incorporated into a soilless medium as a component of the mix. Sorption curves were developed at $25^{\circ} \mathrm{C}$ for attapulgite of two particle sizes $(0.8$ to $1.6 \mathrm{~mm}$ and 1.6 to $3.2 \mathrm{~mm})$, arcillite (1.1 to $\left.3.2 \mathrm{~mm}\right)$, screened pieces of brick (1.0 to $3.6 \mathrm{~mm})$, and a medium of 7 sphagnum peat : 3 perlite (v/v) using solutions of $\mathrm{KH}_{2} \mathrm{PO}_{4}(\mathrm{P}$ at 0 to $20,000 \mathrm{mg} \cdot \mathrm{L}^{-1}$ ). Curves indicated that $\mathrm{PO}_{4}$ and $\mathrm{K}$ sorption were similar for both particle sizes of attapulgite, so only the larger size [1.6 to $3.2 \mathrm{~mm}$ (8 to 16 mesh)] was used in greenhouse studies. Materials were evaluated in greenhouse studies by growing 'Sunny Mandalay' chrysanthemum [Dendranthema $\times$ grandiflora Kitam. (syn. Chrysanthemum $\times$ morifolium Ramat.)]. The precharged materials were tested at $10 \%, 20 \%$, and $30 \%$ by volume of a peat : perlite root medium. Phosphate, $\mathrm{K}$, and $\mathrm{pH}$ were determined on unaltered medium solutions collected throughout the cropping cycle and foliar analyses were determined on tissue collected at midcrop and end of the crop. Data indicated that precharged calcined clays retained and released $\mathrm{PO}_{4}$, and to some degree $\mathrm{K}$, over time. Precharged clays did not provide $\mathrm{K}$ at levels which met plant needs during the latter half of the cropping cycle, but it was released and used at appreciable levels during the first month of crop production. Growth of plants receiving $\mathrm{PO}_{4}$ solely from precharged attapulgite and arcillite at $20 \%$ of the medium volume was not significantly different from that of a commercial control when the leaching fraction was maintained at 0.2 . However, release of $\mathrm{PO}_{4}$ from the brick chips was not enough to match plant demand. Phosphate lost through leaching from the precharged clays was reduced by about two-thirds compared to control plants fertilized with $P$ at $46.5 \mathrm{mg} \cdot \mathrm{L}^{-1}$ from water-soluble fertilizer at each watering.
\end{abstract}

Soilless media, commonly used for container production, consist of high percentages of sphagnum peat or pine bark that have virtually no ability to adsorb and retain $\mathrm{PO}_{4}$ (Marconi and Nelson, 1984 ) in addition to a limited capacity for retention of K. The soilbased mixes used before the introduction of soilless media often had substantial $\mathrm{PO}_{4}$ retention and cation exchange capacities. However, use of soil in mixes lost popularity for a number of reasons, including the need for, and cost associated with, pasteurization and difficulty in securing consistent, high-quality sources (Nelson, 1998).

If a container medium component with high capacity to fix $\mathrm{PO}_{4}$ and/or adsorb cations like $\mathrm{K}$ was precharged with these nutrients before incorporation into the mix, this component could serve as a slow-release fertilizer. This would have to maintain equilibrium concentrations of these nutrients in the root medium solution at levels required to meet plant uptake over the course of the cropping cycle. Ideally, this nutritional system would offer the advantage of

Received for publication 22 July 1999. Accepted for publication 21 June 2000 This research was funded in part by the North Carolina Agricultural Research Service (NCARS), Raleigh, NC 27695-7643 and by a grant from Sun Gro Horticulture, Inc., Bellevue, WA 98009. Use of trade names in this publication does not imply endorsement by the NCARS of products named nor criticism of similar ones not mentioned. We thank William H. Swallow for expert statistical guidance, Wayne P. Robarge for initiating work with the brick chips and manuscript review, and Dean Hesterberg for helpful discussions regarding the isotherms. Appreciation is extended to Yoder Brothers, Inc., Barberton, Ohio 44203 , for providing rooted stem cuttings of chrysanthemum, and to Floridin Company, Quincy, Fla. 32353, for donating attapulgite. From a PhD dissertation submitted by K.A.W. The cost of publishing this paper was defrayed in part by the payment of page charges. Under postal regulations, this paper therefore must be hereby marked advertisement solely to indicate this fact.

${ }^{1}$ Former graduate assistant. Currently Assistant Professor, Dept. of Horticulture, Forestry, and Recreation Resources, 2021 Throckmorton Plant Sciences Center, Kansas State University, Manhattan, KS 66505-5506.

${ }^{2}$ Professor. decreased $\mathrm{PO}_{4}$ and $\mathrm{K}$ losses in the leachate. Most of these nutrients would be retained on a medium component, while only a small proportion would reside in the medium solution subject to leaching. Such a system could also eliminate the need to use $\mathrm{PO}_{4}$ in the liquid fertilization program.

Clays and other constituents derived from soils may serve as root medium components and can be precharged with nutrients. Clays have varying capacities to retain $\mathrm{PO}_{4}$ and cations. For example, 1 : 1 layer silicate clays such as kaolinite consist of alternating silica (tetrahedral) and octahedral sheets. They generally possess a substantial ability to retain $\mathrm{PO}_{4}$, primarily through inner-sphere (covalent) surface complexing at edge surfaces (McBride, 1994). In contrast, 2: 1 layer silicate clays such as montmorillonite consist of an octahedral sheet sandwiched between two tetrahedral sheets. They generally possess substantial cation exchange capacity, which arises from isomorphic substitution and $\mathrm{pH}$-dependent deprotonation of $-\mathrm{OH}$ in the layer silicates. They have a lower capacity for $\mathrm{PO}_{4}$ binding (on a weight basis). Fixation of $\mathrm{K}$, which has an ionic radius that allows it to fit into the siloxane ditrigonal cavity on the basal surface of layer silicates (Sposito, 1989), results from $\mathrm{K}^{+}$entrapment between collapsed layers of $2: 1$ minerals, such as vermiculite (McBride, 1994).

Calcined, or baked, clays could be used to provide structure in a soilless medium and eliminate the need for pasteurization associated with the use of soil. In addition, they could be used at particle sizes which would not interfere with the beneficial physical properties of soilless media. In fact, some waste materials, such as broken pieces of brick, a waste product resulting from the manufacture of brick, may be used for the purpose described.

Warren and Bilderback (1992) studied arcillite, a 2: 1 calcined clay, at varying percentages of amendment in a pine bark-based medium. They found that $\mathrm{P}, \mathrm{K}$, and $\mathrm{NH}_{4}$ concentrations in the root 
Table 1. Exchangeable cations and $\mathrm{P}$ extracted from the calcined clays, attapulgite and arcillite, and from brick chips before charging with $\mathrm{K}$ and $\mathrm{PO}_{4}$ from $\mathrm{KH}_{2} \mathrm{PO}_{4}$.

\begin{tabular}{|c|c|c|c|c|c|}
\hline \multirow[b]{2}{*}{ Material } & $\mathrm{K}$ & $\mathrm{Na}$ & $\mathrm{Ca}$ & $\mathrm{Mg}$ & \multirow{2}{*}{$\begin{array}{c}\mathrm{P} \\
\left(\mu \mathrm{g} \cdot \mathrm{cm}^{-3}\right)\end{array}$} \\
\hline & \multicolumn{4}{|c|}{$\left(\mathrm{mg} \cdot \mathrm{cm}^{-3}\right)$} & \\
\hline Attapulgite, small $^{\mathrm{Z}}$ & 0.42 & 0.09 & 3.46 & 1.93 & 77.9 \\
\hline Attapulgite, large $\mathrm{e}^{\mathrm{y}}$ & 0.63 & 0.09 & 2.77 & 2.57 & 121.9 \\
\hline Arcillite & 0.86 & 0.12 & 1.77 & 0.37 & 18.8 \\
\hline Brick chips & 0.03 & 0.06 & 0.97 & 0.01 & 44.1 \\
\hline
\end{tabular}

${ }^{\mathrm{z}} 0.8$ to $1.6 \mathrm{~mm}$.

y 1.6 to $3.2 \mathrm{~mm}$.

medium derived from the slow-release fertilization program increased with increasing arcillite rate, suggesting that arcillite improved retention of these ions by the medium. Hiller and Koller (1979) reported that arcillite had a high natural content of K and B. Carlile and Bedford (1988) mixed a calcined clay screened from crushed brick waste with peat and observed that $\mathrm{P}$ concentrations were reduced and $\mathrm{Ca}$ concentrations were higher in media containing the clay, compared to a nontreated control. These authors did not speculate about the cause of the reduced $\mathrm{P}$ levels, but explanations may have been $\mathrm{PO}_{4}$ sorption by the clay component or reduced $\mathrm{PO}_{4}$ solubility. Therefore, the objectives of this research were to 1) characterize release of $\mathrm{PO}_{4}$ and $\mathrm{K}$ from precharged calcined clays and brick chips used as a component of a soilless medium over the course of a 10-week cropping cycle, 2) determine the quantity of soluble $\mathrm{PO}_{4}$ leached over time from these media, and 3) determine the effectiveness of these precharged materials at providing $\mathrm{PO}_{4}$ and $\mathrm{K}$ during production of chrysanthemum.

\section{Materials and Methods}

Treatment materials. Two commercial calcined $2: 1$ clays, attapulgite and arcillite, were used in this study. Low volatile matter ( $<3 \%$ moisture) attapulgite (trade name Fuller's Earth) was provided by Floridin Co., Quincy, Fla., at two particle sizes: 0.8 to 1.6 $\mathrm{mm}$ (small; 16 to $30 \mathrm{mesh}$ ), and 1.6 to $3.2 \mathrm{~mm}$ (large; 8 to $16 \mathrm{mesh}$ ). Attapulgite is used commonly as a carrier and diluent for granular formulations of pesticides. Only the large particle size was tested in the greenhouse experiments. Arcillite (trade name Turface, Applied Industrial Materials Corp., Deerfield, Ill.) is a calcined product of the combined clays montmorillonite and illite. Particle size studied was 1.1 to $3.2 \mathrm{~mm}$ ( 8 to 24 mesh). Brick chips consisted of a commercial product marketed under the trade name Brickscape (Cherokee Sanford Group, Inc., Sanford, N.C.) that was screened to a particle range of 1.0 to $3.6 \mathrm{~mm}$ ( 7 to $25 \mathrm{mesh}$ ).

LABORATORY EXPERIMENTS. Mineral extractions were conducted on attapulgite, arcillite, and brick chips to determine concentrations of $\mathrm{P}, \mathrm{K}, \mathrm{Na}, \mathrm{Ca}$, and $\mathrm{Mg}$ present before sorption. Results of initial levels of $\mathrm{P}$ and $\mathrm{K}$ present in the materials were incorporated into curve calculations. A dilute $\mathrm{HCl}$ and $\mathrm{H}_{2} \mathrm{SO}_{4}$ method was used for $\mathrm{P}$ extraction (Olsen and Sommers, 1982) and K, Na, Ca, and $\mathrm{Mg}$ were extracted with $\mathrm{NH}_{4} \mathrm{OAc}$ (Knudsen et al., 1982) (Table 1). Phosphate and $\mathrm{K}$ adsorption curves were created by modifying the procedures described by Fox and Kamprath (1970) and used to select treatments for the greenhouse studies (see Williams et al., 2000).

GREENHOUSE EXPERIMENTS, GENERAL PROCEDURES. The two eXperiments in which the clay materials were tested were described previously (Williams et al., 2000). Experimental materials and procedures that were common to both papers included culture of 'Sunny Mandalay' chrysanthemum; basic physical components of the root medium and preplant amendments; planting, sampling, and harvest dates; and sampling and analytical methods of root medium solution and plant tissue. The following additional procedures were used. Attapulgite, large particle size; arcillite; and brick chips were precharged with $\mathrm{PO}_{4}$ and $\mathrm{K}$ from $\mathrm{P}$ at 2050, 1595, or $275 \mathrm{mg} \cdot \mathrm{L}^{-1}$, respectively, from $\mathrm{KH}_{2} \mathrm{PO}_{4}$.

Treatments were arranged in randomized complete block designs with three blocks and two pots per experimental unit. Data were subjected to analysis of variance procedures (PROC ANOVA, SAS Inst., Cary, N.C.). Least significant differences (LSDS) were calculated to compare means. If the percentage clay by fertilizer treatment interaction was significant, a single LSD was calculated to compare means across both percentage clay levels and fertilizer treatments. If the percentage clay by fertilizer interaction was not significant, two separate LSDS were calculated, one to compare means across percentage clay levels and another to compare means across fertilizer treatments.

GREENHOUSE EXPERIMENT 1: PHOSPHATE AND K RELEASE FROM PRECHARGED ATTAPULGITE, ARCILLITE, AND BRICK CHIPS. Three control treatments were used, each receiving $\mathrm{N}$ at $210 \mathrm{mg} \cdot \mathrm{L}^{-1}$ of the following fertilizers at each watering: the complete fertilizer consisted of $4.5 \mathrm{~mm} \mathrm{KNO}_{3}, 1.5 \mathrm{mM} \mathrm{NH}_{4} \mathrm{H}_{2} \mathrm{PO}_{4}$, and $4.5 \mathrm{~mm} \mathrm{NH}_{4} \mathrm{NO}_{3}(2$ $\mathrm{NH}_{4}-\mathrm{N}: 3 \mathrm{NO}_{3}-\mathrm{N}$ ); the $-\mathrm{P}$ fertilizer consisted of $4.5 \mathrm{~mm} \mathrm{KNO}_{3}$ and $5.25 \mathrm{~mm} \mathrm{NH}_{4} \mathrm{NO}_{3}\left(7 \mathrm{NH}_{4}-\mathrm{N}: 13 \mathrm{NO}_{3}-\mathrm{N}\right)$; and the $-\mathrm{K}$ fertilizer consisted of $1.5 \mathrm{~mm} \mathrm{NH}_{4} \mathrm{H}_{2} \mathrm{PO}_{4}$ and $6.75 \mathrm{~mm} \mathrm{NH}_{4} \mathrm{NO}_{3}\left(11 \mathrm{NH}_{4}-\mathrm{N}\right.$ : $9 \mathrm{NO}_{3}-\mathrm{N}$ ). The leaching fraction (LF), defined as the volume of leachate divided by the volume of solution applied, was estimated at 0.2 . Plants were watered just as the first plants began to develop visible symptoms of water stress.

Control plants were grown in a medium of 7 low-humified sphagnum peat (Sun Gro Horticulture, Inc., Bellevue, Wash.) : 3 coarse perlite (Krum, Silbrico Co., Hodgkins, Ill.) (v/v). Test materials were incorporated into the medium as $10 \%$ or $30 \%$ of the volume of the mix by replacing perlite. These large volumes were used in an effort to decrease the occurrence of zones of localized $\mathrm{PO}_{4}$ depletion in the rhizosphere. The treatment structure was a $2 \times 2 \times$ 3 factorial of two clays (attapulgite and arcillite) by two incorporation proportions (10\% and $30 \%$ of the medium) by three fertilizer treatments (complete fertilizer with uncharged clays, $-\mathrm{P}$ fertilizer with precharged clays, and $-\mathrm{K}$ fertilizer with precharged clays). Only two treatments with brick chips were tested: complete fertilizer with uncharged brick chips comprising $30 \%$ of the medium and -P fertilizer with precharged brick chips comprising $30 \%$ of the medium. The experimental design was a randomized complete block with three blocks and two pots per experimental unit.

GREENHOUSE EXPERIMENT 2: PHOSPHORUS BUDGET. Two fertilizer treatments were used: the complete fertilizer was identical to the formulation used in Expt. 1 and the - $\mathrm{P}$ fertilizer consisted of $4.5 \mathrm{~mm}$ $\mathrm{KNO}_{3}, 4.5 \mathrm{~mm} \mathrm{NH} \mathrm{NO}_{3}$, and $0.75 \mathrm{~mm}\left(\mathrm{NH}_{4}\right)_{2} \mathrm{SO}_{4}$. Both fertilizers contained $2 \mathrm{NH}_{4}-\mathrm{N}: 3 \mathrm{NO}_{3}-\mathrm{N}$. Plants were watered when the weight of the pots decreased by $40 \%$ of container capacity. A measured 

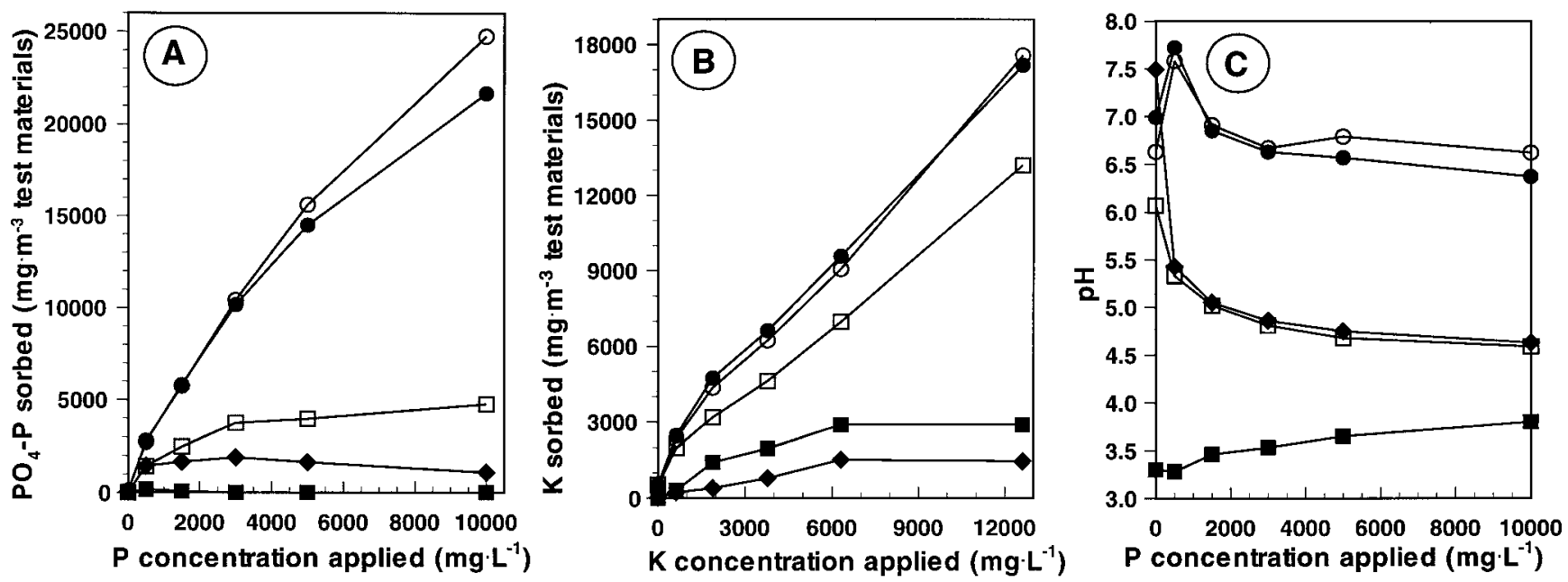

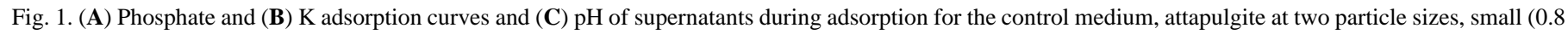
to $1.6 \mathrm{~mm}$ ) and large (1.6 to $3.2 \mathrm{~mm})$; arcillite; and brick chips. In each figure the sE $(\mathrm{n}=3)$ for every data point is smaller than the graphed symbol; ( $\mathbf{\square})$ control medium; (๑) attapulgite, large; (○) attapulgite, small; $(\square)$ arcillite; and ( $\bullet$ ) brick chips.

volume of fertilizer solution containing $\mathrm{N}$ at $210 \mathrm{mg} \cdot \mathrm{L}^{-1}$ was applied at each watering to result in a controlled LF of 0.2 .

Control plants were grown in the same medium as Expt. 1, 7 peat : 3 perlite $(\mathrm{v} / \mathrm{v})$. Precharged attapulgite and arcillite were incorporated into the medium to comprise $20 \%$ of the volume and peat : perlite ratios were adjusted to result in physical properties more similar to the control treatments: 6.5 peat : 1.5 perlite : 2 precharged clay $(\mathrm{v} / \mathrm{v})$. The precharged brick chips were again tested at $30 \%$ of the volume of the mix, but the ratio of components was altered to 6 peat : 1 perlite : 3 brick chips $(\mathrm{v} / \mathrm{v})$.

\section{Results and Discussion}

LABORATORY EXPERIMENTS. Adsorption data indicated that 7 peat : 3 perlite medium $(\mathrm{v} / \mathrm{v})$ had almost no facility to retain $\mathrm{PO}_{4}$ and only limited ability to retain $\mathrm{K}$ in the $\mathrm{pH}$ range of supernatants encountered in this study (Fig. 1A and B). Potassium retention was sizeable in both attapulgite and arcillite, which was predictable based on the $2: 1$ structure of these clays. Attapulgite had a remarkable facility to retain $\mathrm{PO}_{4}$. Attapulgite retention of $\mathrm{PO}_{4}$ was up to five times greater than arcillite at the highest rate of charge (Fig. 1A). The nearly overlapping curves for attapulgite treatments of large and small particle sizes suggested only a slight difference in their capacity to retain $\mathrm{PO}_{4}$, especially at the lower levels of charge, and even less difference in their ability to retain $\mathrm{K}$ (Fig. 1A and B); thus, the larger of the two particle sizes was chosen for testing in the greenhouse studies.

The $\mathrm{PO}_{4}$ adsorption curves for brick chips indicated a potential for $\mathrm{PO}_{4}$ retention. However, $\mathrm{K}$ retention by this material was lower than that of the peat : perlite medium, so K retention by brick chips was not studied in greenhouse experiments (Fig. 1). The pH levels measured in the supernatants suggested that attapulgite might raise the $\mathrm{pH}$ level in the root medium and that arcillite and brick would have less influence on $\mathrm{pH}$ (Fig. 1C).

Greenhouse EXPERIMENT 1. Statistical analysis of the factorial treatment set of calcined clays indicated no significant difference in results of plant growth characteristics between attapulgite and arcillite (Table 2). However, the fertilizer treatment was highly significant for all growth characteristics. Treatment means showed that plants relying on precharged clays to meet their K needs did not produce growth equivalent to other treatments. Percent (by volume) of the clay amendment which comprised the root medium resulted in significantly different results for three of the five growth characteristics. However, the direction of the effect of the clay proportion in the medium varied among fertilizer regimes. For example, precharged attapulgite with -P fertilizer at $10 \%$ of the mix resulted in slightly better growth than attapulgite at $30 \%$ of the mix. The opposite tended to be true for the precharged with $-\mathrm{K}$ fertilizer and uncharged attapulgite treatments. These relationships explain the significant percentage $($ Pct $) \times$ fertilizer $($ Fert $)$ interaction, which was the only consistently significant interaction (Table 2 ).

Plants that received $\mathrm{PO}_{4}$ only from precharged calcined clays and brick chips had slightly reduced growth compared to the complete control (Table 2). At midcrop, tissue P levels (Table 3) of these treatments were above the accepted standard minimum critical level of $0.25 \%$ (Mills and Jones, 1996). By end of the crop, the P levels of these treatments met the minimum critical value of $0.20 \%$ (Mills and Jones, 1996) except brick chips which resulted in a tissue P level of $0.19 \%$. Another reason to consider the $\mathrm{P}$ tissue concentrations adequate is that the standards are based on analysis of recently matured leaves, while the tissue analyzed at end of the crop in this study was whole shoots. One would expect whole shoots to have lower tissue concentrations of the mobile nutrients $\mathrm{N}, \mathrm{P}, \mathrm{K}$, and $\mathrm{Mg}$ compared to leaves due to dilution from stem, flowers, and older foliage. The higher tissue concentrations found in the complete control suggested luxury consumption of $\mathrm{PO}_{4}$ from high application rates of the complete fertilizer. In the complete control and plants grown with $10 \%$ and $30 \%$ precharged calcined clays and brick chips with -P fertilizer, adequate levels of all other essential nutrients were found at the midpoint (data not presented) and end of the crop. This includes $\mathrm{S}$ and $\mathrm{B}$, which were spot-checked (data not presented). A few exceptions were noted for $\mathrm{Ca}$ and $\mathrm{Cu}$ at end of the crop, but these levels surpassed the complete control concentrations, which showed no signs of deficiency. Thus, it could be argued that reduction in growth of plants grown with precharged calcined clays and $-\mathrm{P}$ fertilizer was not likely due to mineral nutrient deficiency. The possible exception was brick chips.

The root medium solution $\mathrm{PO}_{4}$ concentrations for plants grown with precharged calcined clays and brick were apparently adequate throughout the cropping cycle, with solution $\mathrm{PO}_{4}-\mathrm{P}$ concentrations 
remaining above the minimum critical level of $0.2 \mathrm{mg} \cdot \mathrm{L}^{-1}$ established by Nishimoto et al., (1975) (Fig. 2A and B). The sole exception was observed for precharged brick chips on day 70 of the cropping cycle, when $\mathrm{PO}_{4}-\mathrm{P}$ levels in the medium solution were $0.1 \mathrm{mg} \cdot \mathrm{L}^{-1}$. The $\mathrm{PO}_{4}$ levels in the root medium solution were substantially higher from precharged clays which comprised $30 \%$ of the medium compared to those of media with $10 \%$ clay. It is important to note that the solution nutrient concentrations are a snapshot of levels in solution. During the 1-h period between irrigation and solution sampling, the $\mathrm{PO}_{4}$ levels would also be affected by plant uptake. As the plants became larger over the course of the cropping cycle, they were able to deplete the medium solution of nutrients faster.

The high $\mathrm{pH}$ of the medium solutions after the first month of the cropping cycle for plants fertilized with the-P fertilizer as compared to the complete control (Fig. 2E and F) may explain part of the reduced growth resulting from use of precharged attapulgite, arcillite, and brick chips. High $\mathrm{pH}$ may result in decreased availability of $\mathrm{PO}_{4}$ or micronutrient cations. While the high $\mathrm{pH}$ levels could have resulted directly from the clays and brick themselves, it might also have been influenced by differences in fertilizer formulations of the complete and $-\mathrm{P}$ fertilizers. The complete fertilizer contained a higher percent $\mathrm{NH}_{4}-\mathrm{N}$ than the $-\mathrm{P}$ fertilizer, which would tend to adjust the $\mathrm{pH}$ downward over the course of the cropping cycle. In Expt. 2, these fertilizers were altered to provide the same $\mathrm{NH}_{4}: \mathrm{NO}_{3}$ ratio; the ions which were varied were $\mathrm{Ca}$ and $\mathrm{SO}_{4}$.

Physical properties may also have played a role in reducing the growth of plants grown with precharged clays and brick at $10 \%$ and $30 \%$ of the medium. The mixes in which the clay comprised $30 \%$ of the volume and replaced all perlite had a finer texture than the

Table 2. Growth measurements for shoot growth at the end of the crop (day 71) of 'Sunny Mandalay' chrysanthemums grown with attapulgite, arcillite, and brick chips comprising $10 \%$ and $30 \%$ of the medium, and a peat-based control medium (Expt. 1).

\begin{tabular}{|c|c|c|c|c|c|c|}
\hline Source & $\begin{array}{l}\text { Mix } \\
(\%)\end{array}$ & $\begin{array}{l}\mathrm{Ht} \\
(\mathrm{cm})\end{array}$ & $\begin{array}{l}\text { Width } \\
(\mathrm{cm})\end{array}$ & $\begin{array}{c}\text { Fresh } \\
\text { wt } \\
(\mathrm{g})\end{array}$ & $\begin{array}{l}\text { Dry } \\
\text { wt } \\
(\mathrm{g})\end{array}$ & Rating $^{z}$ \\
\hline \multicolumn{7}{|l|}{ Control medium } \\
\hline Complete fertilizer $^{y}$ & & 20.2 & 30.0 & 162.6 & 16.3 & 10.0 \\
\hline -P fertilizer & & 8.0 & 8.5 & 6.4 & 1.0 & 1.0 \\
\hline$-\mathrm{K}$ fertilizer & & 10.4 & 15.4 & 39.2 & 3.0 & 1.7 \\
\hline $\operatorname{LSD}_{0.05}{ }^{\mathrm{x}}$ & & 1.8 & 3.1 & 24.5 & 3.1 & 1.8 \\
\hline \multicolumn{7}{|l|}{-P fertilizer, precharged clays } \\
\hline \multirow[t]{2}{*}{ Attapulgite } & 10 & 19.0 & 27.4 & 133.2 & 15.2 & 9.7 \\
\hline & 30 & 17.8 & 27.3 & 124.7 & 12.0 & 8.7 \\
\hline \multirow[t]{2}{*}{ Arcillite } & 10 & 19.1 & 27.8 & 113.3 & 14.2 & 8.7 \\
\hline & 30 & 19.0 & 28.1 & 129.5 & 13.7 & 9.3 \\
\hline Brick chips & 30 & 18.8 & 25.7 & 100.6 & 11.7 & 9.0 \\
\hline \multicolumn{7}{|l|}{-K fertilizer, precharged clays } \\
\hline \multirow[t]{2}{*}{ Attapulgite } & 10 & 16.3 & 22.5 & 78.9 & 8.7 & 4.0 \\
\hline & 30 & 17.5 & 25.5 & 97.2 & 9.7 & 6.3 \\
\hline \multirow[t]{2}{*}{ Arcillite } & 10 & 15.4 & 22.8 & 74.9 & 8.1 & 4.3 \\
\hline & 30 & 18.3 & 27.5 & 103.5 & 11.1 & 7.7 \\
\hline \multicolumn{7}{|c|}{ Complete fertilizer, uncharged clays } \\
\hline \multirow[t]{2}{*}{ Attapulgite } & 10 & 18.8 & 30.1 & 144.8 & 12.1 & 9.3 \\
\hline & 30 & 20.3 & 30.4 & 146.7 & 14.1 & 8.7 \\
\hline \multirow[t]{2}{*}{ Arcillite } & 10 & 19.5 & 30.9 & 161.2 & 15.9 & 10.0 \\
\hline & 30 & 19.6 & 29.8 & 138.5 & 15.1 & 8.7 \\
\hline Brick chips & 30 & 20.3 & 30.1 & 147.6 & 15.8 & 10.0 \\
\hline $\mathrm{LSD}_{0.05}{ }^{\mathrm{w}}$ & & 1.4 & 2.5 & 21.8 & 2.7 & 1.0 \\
\hline \multicolumn{7}{|l|}{ Significance $^{\mathrm{v}}$} \\
\hline \multicolumn{7}{|c|}{ Percent volume of clay in medium: $10 \%$ or $30 \%$ (Pct) } \\
\hline \multicolumn{7}{|c|}{ Fertilizer applied: $-\mathrm{P},-\mathrm{K}$, or complete (Fert) } \\
\hline \multicolumn{7}{|c|}{ Calcined clay: attapulgite or arcillite (Clay) } \\
\hline Pct & & $*$ & $*$ & NS & NS & $*$ \\
\hline Fert & & $* * *$ & $* * *$ & $* * *$ & $* * *$ & $* * *$ \\
\hline Clay & & NS & NS & NS & NS & NS \\
\hline Pct $\times$ Fert & & $* *$ & $* *$ & $* *$ & $*$ & $* * *$ \\
\hline Pct $\times$ Clay & & NS & NS & NS & NS & NS \\
\hline Fert $\times$ Clay & & NS & NS & NS & NS & NS \\
\hline Pct $\times$ Fert $\times$ Clay & & NS & NS & $*$ & NS & NS \\
\hline
\end{tabular}

\footnotetext{
${ }^{\mathrm{z}}$ Scale of 1 to 10 with $1=$ death and $10=$ optimum commercial growth.

yComplete control.

${ }^{\mathrm{x}} \mathrm{LSD}$ used to compare clay treatments within a given fertilizer treatment $(-\mathrm{P},-\mathrm{K}$, or complete) to the control medium.

${ }^{\mathrm{w}}$ LSD used to compare brick chips means of both $-\mathrm{P}$ and complete fertilizer treatments with other treatment means.

${ }^{v}$ Factorial treatment analysis of two calcined clays $\times$ two percentage of mix $\times$ three fertilizers.

ns,*,**,*** Nonsignificant or significiant at $P=0.05,0.01$, or 0.001 , respectively.
} 
control resulting in reduced air-filled porosity and increased water retention (Table 4). This difference was accentuated by watering all plants on the same schedule so that smaller plants were watered too often. The mixes were reformulated for Expt. 2 by adjusting the peat to perlite ratios to yield a coarser texture thereby increasing the airfilled porosity in the mixes containing clays.

Although the LF was estimated to be 0.2 in Expt. 1, the method of watering did not allow for careful control. This could have resulted in excessive loss of $\mathrm{PO}_{4}$ which would not have occurred with a lesser LF or subirrigation. In Expt. 2, to improve the accuracy of leaching and to water each treatment based on the individual need of those plants, water was applied by precise weight measurements as described previously. Thus, any differences in available water of the different media were balanced.

Growth of plants that relied on precharged clays to meet their $\mathrm{K}$ requirement was significantly less than the complete control (Table 2). Symptoms indicative of K deficiency, including necrotic lesions on the lower foliage, were observed on the treatment plants. The

Table 3. Phosphorus and K content (dry weight basis) of the youngest fully expanded leaves collected at midcrop (day 43) and mineral content of whole shoots at end of the crop (day 71) of 'Sunny Mandalay' chrysanthemums grown with attapulgite, arcillite, and brick chips comprising 10\% and $30 \%$ of the medium, and a peat-based control medium (Expt. 1).

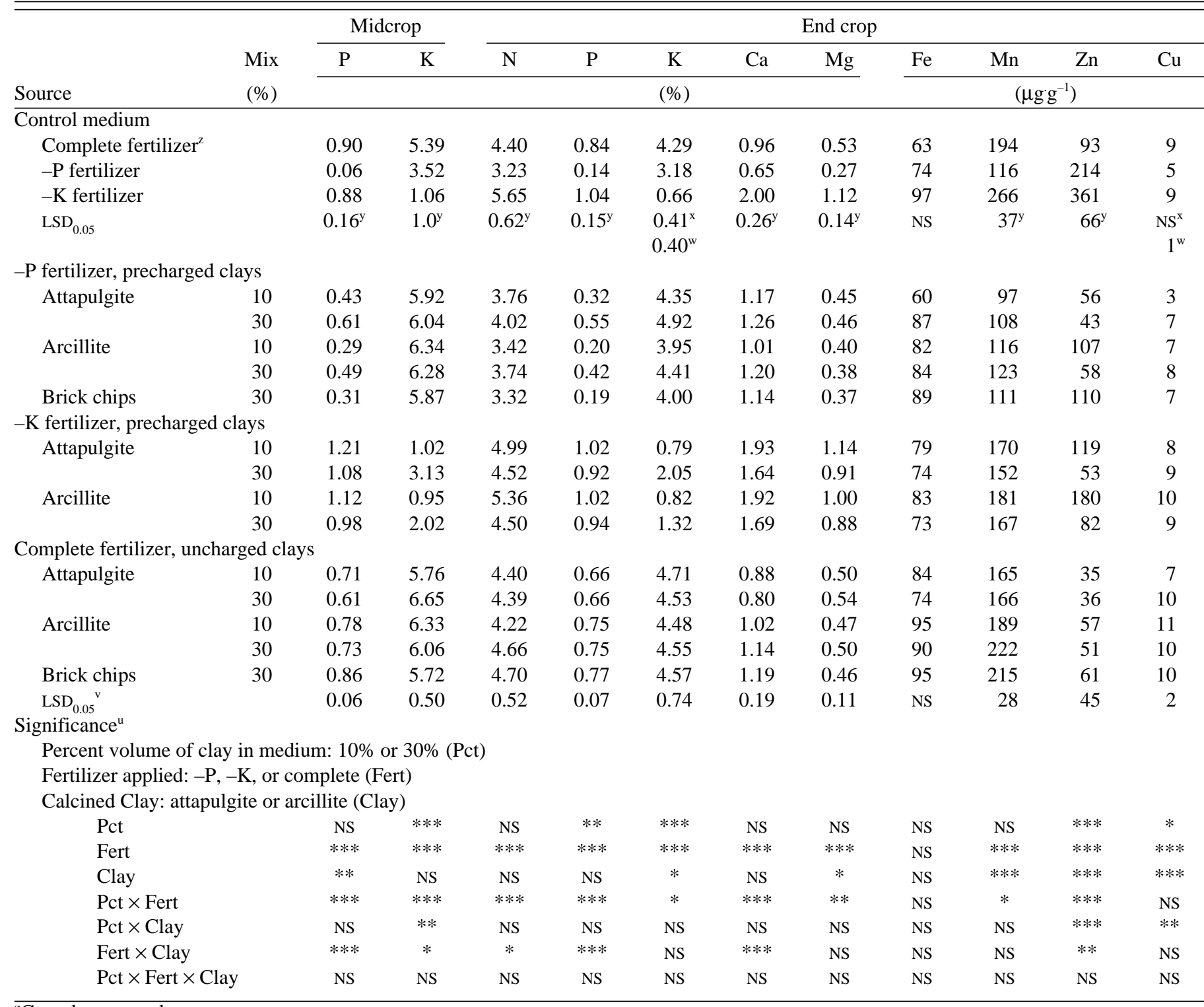

\footnotetext{
${ }^{\mathrm{z} C o m p l e t e}$ control.
}

${ }^{\mathrm{L}} \mathrm{LSD}$ used to compare clay treatments within a given fertilizer treatment $(-\mathrm{P},-\mathrm{K}$, or complete) to the control medium. Pct $\times$ Fert interaction is significant.

${ }^{\mathrm{x}}$ LSD used to compare clay treatments at a percent level $(10 \%$ or $30 \%)$ of a fertilizer treatment $(-\mathrm{P},-\mathrm{K}$, or complete) to the control medium. Pct $\times$ Fert interaction is nonsignificant.

${ }^{\mathrm{w}} \mathrm{LSD}$ used to compare clay treatments of a fertilizer treatment $(-\mathrm{P},-\mathrm{K}$, or complete) at a percent level (10\% or $30 \%)$ to the control medium. Pct $\times$ fert interaction is nonsignificant.

$\mathrm{v}_{\text {LSD }}$ used to compare brick chips means of both $-\mathrm{P}$ and complete fertilizer treatments with other treatment means.

uFactorial treatment analysis of two calcined clays by $2 \%$ of mix by three fertilzers.

ns,*,**,*** Nonsignificant or significant at $P=0.05,0.01$ or 0.0001 , respectively. 

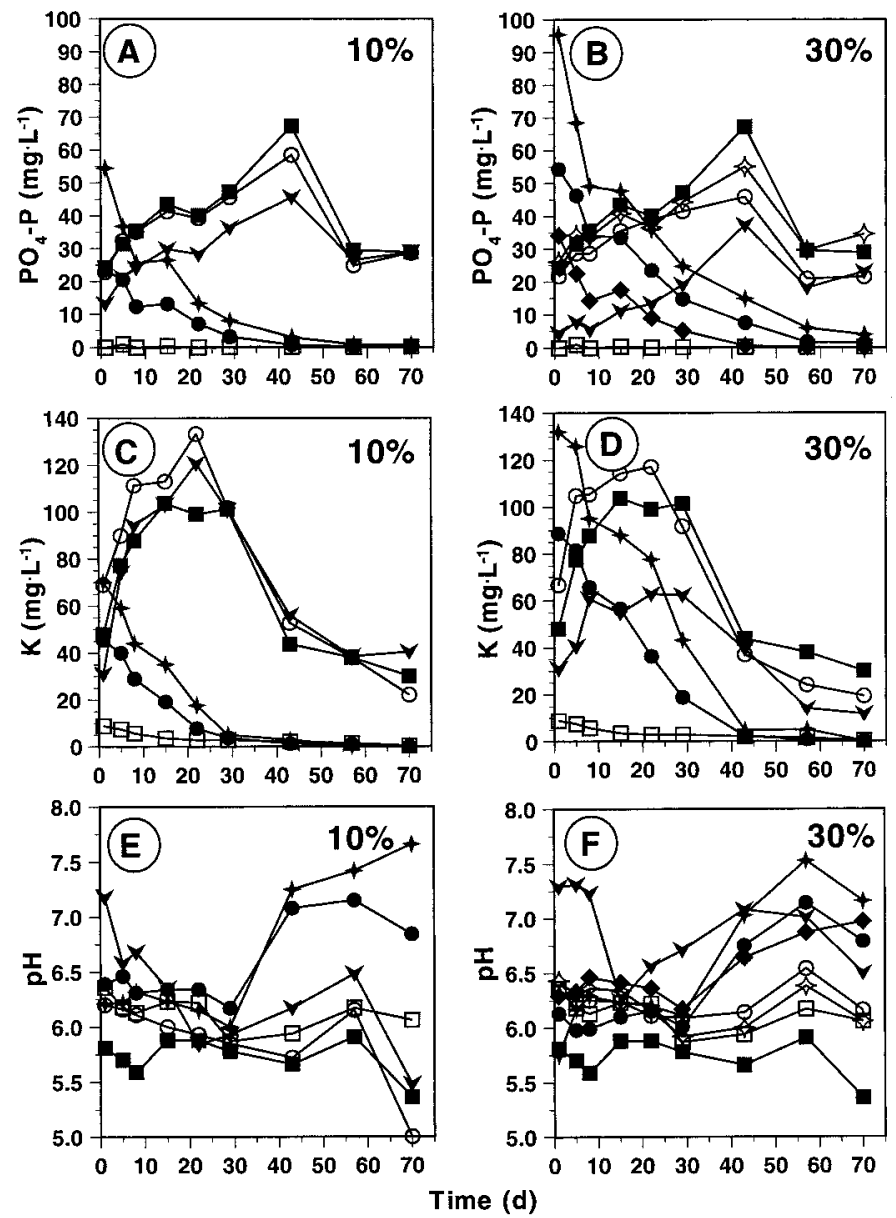

Fig. 2. Mineral nutrient concentrations of unaltered bulk root medium solution during greenhouse Expt. 1 of media treated with precharged calcined clays, brick chips, and controls. (A and B) $\mathrm{PO}_{4}-\mathrm{P}(\mathrm{SE}= \pm 1.8)$; (C and D) $\mathrm{K}(\mathrm{SE}= \pm 5.4)$, and $(\mathbf{E}$ and $\mathbf{F}) \mathrm{pH}$ of precharged and uncharged treatments, $(\mathrm{SE}= \pm 0.1) ;(\mathbf{\square})$ complete control; ( $\square)-\mathrm{P}$ or $-\mathrm{K}$ fertilizer; $(+)$ precharged attapulgite, $10 \%$ or $30 \%$ of mix, with $-\mathrm{P}$ or $-\mathrm{K}$ fertilizer; $(\mathbf{O})$ precharged arcillite, $10 \%$ or $30 \%$ of mix, with $-\mathrm{P}$ or $-\mathrm{K}$ fertilizer; $(\diamond)$ precharged brick chips, $30 \%$ of mix, with P fertilizer; $(\mathbf{V})$ uncharged attapulgite, $10 \%$ or $30 \%$ of mix; $(\bigcirc)$ uncharged arcillite, $10 \%$ or $30 \%$ of mix; and $(\diamond)=$ uncharged brick chips, $30 \%$ of mix. In all figures each symbol is based on three observations (two plants were used to obtain each observation). tissue $\mathrm{K}$ levels (Table 3 ) of these plants were inadequate at both the midpoint and end of the crop, although concentrations were significantly higher in plants grown with $30 \%$ as compared to $10 \%$ of the precharged clay. The medium solution $\mathrm{K}$ levels indicated that $\mathrm{K}$ release from the precharged clays was substantial for the first 25 to $35 \mathrm{~d}$ of the cropping cycle (Fig. $2 \mathrm{C}$ and D). By day 22 , K release dropped below $10 \mathrm{mg} \cdot \mathrm{L}^{-1}$ for precharged arcillite at $10 \%$ of the medium; by day 29, it had dropped below this threshold for precharged attapulgite at $10 \%$ of the mix; and by day 43 , K levels were below $10 \mathrm{mg} \cdot \mathrm{L}^{-1}$ for both precharged clays comprising $30 \%$ of the medium. These levels were inadequate to meet plant demands for optimal growth, as determined by plant appearance. Thus, the $\mathrm{K}$ from precharging the clays could provide some of the $\mathrm{K}$ needed during chrysanthemum production, but this source alone was inadequate to sustain plant needs.

Growth characteristics of plants grown in uncharged clays and brick chips were generally not significantly different from the complete control, except that dry weight of plants grown in $10 \%$ attapulgite was lower (Table 2). Medium solution $\mathrm{PO}_{4}-\mathrm{P}$ concentrations (Fig. 2A and B) were lower in the uncharged attapulgite treatments than the complete control. This suggested that the uncharged attapulgite removed $\mathrm{PO}_{4}$ from solution until sorption sites were saturated, perhaps for as long as $57 \mathrm{~d}$ of the cropping cycle, during which time less $\mathrm{P}$ was available for uptake by the plant. Uncharged arcillite and brick chips had little effect on the $\mathrm{PO}_{4}-\mathrm{P}$ levels recovered in the bulk medium solution. Uncharged attapulgite at $30 \%$ of the mix was the only clay treatment which appeared to reduce $\mathrm{K}$ available for plant uptake by removing it from solution (Fig. $2 \mathrm{C}$ and D).

GREENHOUSE EXPERIMENT 2. Growth of plants in $20 \%$ precharged attapulgite and arcillite and $-\mathrm{P}$ fertilizer was not significantly different than that of the complete control based on all five growth characteristics. Precharged brick chips resulted in less growth (except height) than the complete control (Table 5). Tissue analyses confirmed that $\mathrm{P}$ levels were optimal at both the midpoint and end of the crop for plants grown with a precharged clay. Phosphorus recovered in plants grown with precharged brick chips as their sole $\mathrm{PO}_{4}$ source also met the minimum critical $\mathrm{P}$ levels, but was significantly less than in plants grown with $20 \%$ precharged clays and the complete control (Table 6). The medium solution $\mathrm{PO}_{4}-\mathrm{Plevels}$ (Fig. $3 \mathrm{~A})$ were similar to those observed in Expt. 1 with levels for $20 \%$

Table 4. Physical properties characteristics of root medium formulations used in Expts. 1 and 2 as measured in a 10-cm-deep, 10-cm-round (0.05-L pot), plastic pot following the procedures of Niedziela and Nelson (1992).

\begin{tabular}{|c|c|c|c|c|c|}
\hline Medium & $\begin{array}{c}\text { Bulk } \\
\text { density }\end{array}$ & $\begin{array}{l}\text { Particle } \\
\text { density }\end{array}$ & $\begin{array}{c}\text { Air-filled } \\
\text { porosity }\end{array}$ & $\begin{array}{l}\text { Container } \\
\text { capacity }\end{array}$ & $\begin{array}{c}\text { Total } \\
\text { porosity }\end{array}$ \\
\hline \multirow[t]{2}{*}{$(\mathrm{v} / \mathrm{v})$} & $\left(\mathrm{g} \mathrm{cm}^{-3}\right)$ & $\left(\mathrm{gcm}^{-3}\right)$ & \multicolumn{3}{|c|}{$(\%)$} \\
\hline & \multicolumn{5}{|c|}{ Expt. 1} \\
\hline 7 peat : 3 perlite & 0.17 & 0.96 & 11.7 & 68.0 & 79.7 \\
\hline 7 peat : 2 perlite : 1 attapulgite & 0.20 & 0.97 & 9.0 & 68.2 & 77.2 \\
\hline 7 peat : 3 attapulgite & 0.33 & 1.95 & 8.1 & 72.6 & 80.7 \\
\hline 7 peat : 2 perlite: 1 arcillite & 0.22 & 1.08 & 9.5 & 68.0 & 77.5 \\
\hline 7 peat : 3 arcillite & 0.37 & 2.09 & 7.6 & 72.2 & 79.8 \\
\hline \multirow[t]{2}{*}{$\operatorname{LSD}_{0.05}$} & 0.03 & 0.45 & 3.3 & 3.6 & NS \\
\hline & \multicolumn{5}{|c|}{ Expt. 2} \\
\hline 7 peat : 3 perlite & 0.20 & 2.20 & 13.3 & 74.8 & 88.1 \\
\hline 6.5 peat : 1.5 perlite : 2 attapulgite & 0.25 & 2.33 & 13.5 & 73.1 & 86.6 \\
\hline 6.5 peat : 1.5 perlite: 20 arcillite & 0.27 & 2.50 & 16.7 & 69.2 & 85.9 \\
\hline 6 peat : 1 perlite : 3 brick chips & 0.39 & 1.90 & 12.8 & 64.6 & 77.4 \\
\hline $\mathrm{LSD}_{0.05}$ & 0.06 & NS & NS & 4.5 & 6.3 \\
\hline
\end{tabular}

NSNonsignificant. 
Table 5. Plant growth characteristics for shoots at end of the crop (day 67) of 'Sunny Mandalay' chrysanthemums grown with precharged calcined clays comprising $20 \%$ of the medium, brick chips comprising $30 \%$ of the medium, and a peat-based control medium (Expt. 2).

\begin{tabular}{|c|c|c|c|c|c|c|}
\hline Source & $\begin{array}{l}\text { Mix } \\
(\%)\end{array}$ & $\begin{array}{c}\mathrm{Ht} \\
(\mathrm{cm})\end{array}$ & $\begin{array}{l}\text { Width } \\
(\mathrm{cm})\end{array}$ & $\begin{array}{c}\text { Fresh wt } \\
(\mathrm{g})\end{array}$ & $\begin{array}{l}\text { Dry wt } \\
(\mathrm{g})\end{array}$ & Rating $^{\mathrm{z}}$ \\
\hline \multicolumn{7}{|l|}{ Control medium } \\
\hline Complete fertilizer ${ }^{y}$ & & 22.3 & 38.5 & 144.7 & 16.1 & 10.0 \\
\hline$-\mathrm{P}$ fertilizer & & 14.7 & 17.2 & 13.7 & 3.3 & 2.0 \\
\hline \multicolumn{7}{|l|}{ Precharged clays } \\
\hline Attapulgite & 20 & 22.0 & 38.3 & 146.7 & 16.1 & 10.0 \\
\hline Arcillite & 20 & 21.8 & 38.1 & 141.4 & 16.4 & 10.0 \\
\hline Brick chips & 30 & 22.3 & 35.0 & 116.2 & 13.7 & 9.3 \\
\hline $\operatorname{LSD}_{00.05}$ & & 1.9 & 2.6 & 9.1 & 1.6 & 0.5 \\
\hline
\end{tabular}

${ }^{\mathrm{z}}$ Scale of 1 to 10 with $1=$ death and $10=$ optimum commercial growth.

yComplete control.

Table 6. Mineral nutrient content (dry weight basis) of the youngest fully expanded leaves collected at midcrop (day 36) and of whole shoots at end of the crop (day 67) of 'Sunny Mandalay' chrysanthemums grown with precharged calcined clays comprising $20 \%$ of the medium, brick chips comprising $30 \%$ of the medium, and a peat-based control medium (Expt. 2).

\begin{tabular}{|c|c|c|c|c|c|c|c|c|c|c|c|c|}
\hline \multirow[b]{3}{*}{ Source } & \multirow{3}{*}{$\begin{array}{l}\text { Mix } \\
(\%)\end{array}$} & \multicolumn{11}{|c|}{ Mineral } \\
\hline & & $\mathrm{N}$ & $\mathrm{P}$ & $\mathrm{K}$ & $\mathrm{Ca}$ & $\mathrm{Mg}$ & $S$ & $\mathrm{Fe}$ & $\mathrm{Mn}$ & $\mathrm{Zn}$ & $\mathrm{Cu}$ & B \\
\hline & & \multicolumn{6}{|c|}{$(\%)$} & \multicolumn{5}{|c|}{$\left(\mu \mathrm{g} \cdot \mathrm{g}^{-1}\right)$} \\
\hline & & \multicolumn{11}{|c|}{ Midcrop } \\
\hline \multicolumn{13}{|l|}{ Control medium } \\
\hline Complete fertilizer ${ }^{2}$ & & 4.94 & 0.64 & 3.88 & 0.91 & 0.56 & --- & 69 & 503 & 383 & 15 & --- \\
\hline -P fertilizer & & 3.29 & 0.10 & 3.93 & 0.47 & 0.27 & --- & 59 & 487 & 410 & 17 & --- \\
\hline \multicolumn{13}{|l|}{ Precharged clays } \\
\hline Attapulgite & 20 & 5.03 & 0.58 & 5.40 & 0.85 & 0.43 & --- & 56 & 525 & 80 & 12 & --- \\
\hline Arcillite & 20 & 4.84 & 0.45 & 4.79 & 0.85 & 0.35 & --- & 91 & 754 & 185 & 14 & --- \\
\hline Brick chips & 30 & 5.13 & 0.38 & 4.46 & 0.94 & 0.53 & --- & 71 & 896 & 184 & 18 & --- \\
\hline $\mathrm{LSD}_{0.05}$ & & 0.42 & 0.05 & 0.41 & 0.05 & 0.04 & & 8 & 111 & 72 & 2 & \\
\hline & & \multicolumn{11}{|c|}{ End crop } \\
\hline \multicolumn{13}{|l|}{ Control medium } \\
\hline Complete fertilizer ${ }^{2}$ & & 3.94 & 0.79 & 3.79 & 0.89 & 0.53 & 0.21 & 64 & 269 & 439 & 15 & 46 \\
\hline$-\mathrm{P}$ fertilizer & & 2.91 & 0.09 & 3.44 & 0.63 & 0.33 & 0.23 & 58 & 604 & 737 & 23 & 67 \\
\hline \multicolumn{13}{|l|}{ Precharged clays } \\
\hline Attapulgite & 20 & 4.21 & 0.46 & 4.65 & 1.04 & 0.46 & 0.25 & 72 & 277 & 121 & 15 & 48 \\
\hline Arcillite & 20 & 3.86 & 0.31 & 4.13 & 0.95 & 0.41 & 0.35 & 72 & 326 & 306 & 16 & 53 \\
\hline Brick chips & 30 & 3.49 & 0.23 & 4.28 & 1.01 & 0.50 & 0.31 & 76 & 380 & 329 & 22 & 57 \\
\hline $\mathrm{LSD}_{0.05}$ & & 0.35 & 0.06 & 0.38 & 0.08 & 0.05 & 0.05 & NS & 80 & 92 & 2 & NS \\
\hline
\end{tabular}

${ }^{\mathrm{z} C o m p l e t e}$ control.

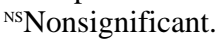

precharged clays in Expt. 2 falling approximately between levels from Expt. 1 for $10 \%$ and $30 \%$ precharged clays. Late in the cropping cycle, $\mathrm{PO}_{4}$-P levels in the root medium did not fall below $0.2 \mathrm{mg} \cdot \mathrm{L}^{-1}$ for plants grown in precharged clays which comprised $20 \%$ of the medium. However, $\mathrm{PO}_{4}-\mathrm{P}$ levels dropped below the critical level of $0.2 \mathrm{mg} \cdot \mathrm{L}^{-1}$ by day 57 of the cropping cycle for plants grown with $30 \%$ precharged brick chips (Fig. 3A). Ideally, release of $\mathrm{PO}_{4}$ from the test materials would not be so high during the first half of the cropping cycle, but instead, sustained at lower levels for the duration of crop production. Potassium levels in plants grown with precharged clays (Table 6) were significantly higher than in the complete control, which may be in part attributed to superoptimal release of $\mathrm{K}$ from the precharged clays early in the cropping cycle. This led to luxury consumption as observed in Expt. 1.

The $\mathrm{pH}$ of medium solution from plants grown with precharged clays and brick chips was again 1 to 2 units higher than in the control plants (Fig. 3B), similar to the results in Expt. 1 (Fig. 2E and F). This indicated that the differences in fertilizer $\mathrm{NH}_{4}: \mathrm{NO}_{3}$ ratio had little effect on medium $\mathrm{pH}$, compared to the effects of the test materials themselves. Similar increases in $\mathrm{pH}$ of soilless media were observed by Warren and Bilderback (1992) in an experiment with arcillite and by Carlile and Bedford (1988) in a study with waste from brick production.

In Expt. 1,30\% precharged clays did not result in growth similar to the complete control (Table 2), but they did in Expt. 2 at a volume of $20 \%$ of the mix. This result in Expt. 2 could be attributed to the more carefully controlled watering procedures which likely reduced leaching and/or increased aeration in the root medium due to the changes in media formulation.

A P budget showed that $36 \%$ (103 mg) of the applied $\mathrm{PO}_{4}$ of the complete control treatment was lost in the leachate, whereas only $5.9 \%$ (36.1 mg) and $18.4 \%$ (21.6 mg) were lost from the precharged attapulgite and arcillite treatments, respectively (Table 7). The lesser amounts of $\mathrm{PO}_{4}$ recovered by the plants grown with precharged clays compared to the complete control did not indicate inadequate $\mathrm{PO}_{4}$. Instead, it was an indication of luxury consumption of $\mathrm{PO}_{4}$ by 
Fig. 3. Phosphate concentration and $\mathrm{pH}$ of unaltered bulk root medium solution during greenhouse Expt. 2 of root media treated with precharged calcined clays and brick chips and complete control. (A) $\mathrm{PO}_{4}-\mathrm{P}(\mathrm{SE}= \pm 1.3)$ and $(\mathbf{B}) \mathrm{pH}$ $(\mathrm{SE}= \pm 0.1)$; $(\mathbf{\square})$ complete control; $(\square)-$ P fertilizer; (+) $=$ precharged attapulgite, $20 \%$ of mix; (O) precharged arcillite, $20 \%$ of mix; and ( $)$ precharged brick chips, $30 \%$ of mix. In all figures each symbol is based on three observations (two plants were used to obtain each observation).

the complete control. Substantial amounts of the $\mathrm{PO}_{4}$ applied as precharged clays remained in pots at the end of the crop and were not used during crop production.

The use of precharged clays in soilless media can provide $\mathrm{PO}_{4}$ to meet chrysanthemum needs during production. Their ability to successfully meet plant $\mathrm{K}$ needs was not demonstrated by this research. Brick chips supplied adequate $\mathrm{PO}_{4}$ over the 10 week cropping cycle. The release of $\mathrm{PO}_{4}$ over the course of the cropping cycle from the precharged clays was not ideal, with levels wastefully high early during production and decreasing to just above the minimum critical levels toward the end of production. However, these studies showed that a clay-based amendment can provide the capacity to retain and release $\mathrm{PO}_{4}$ in a soilless container medium. Other clays or altered calcining processes may provide greater facility for $\mathrm{PO}_{4}$ and $\mathrm{K}$ retention and release as a basis for this alternative slow-release fertilizer.

\section{Literature Cited}

Carlile, W.R. and I. Bedford. 1988. Plant growth in container media amended with calcined clay. Acta Hort. 221:117-132.

Fox, R.L. and E.J. Kamprath. 1970.Phosphate sorption isotherms for evaluating the phosphate requirements of soils. Soil Sci. Soc. Amer. Proc. 34:902-906.

Hiller,L.K. andD.C. Koller. 1979. Potato growth responses in arcillite and sand. HortScience 14:534-536.

Knudsen, D., G.A. Peterson, and P.F. Pratt. 1982. Lithium, sodium, and potassium, p. 225-246. In: A.L. Page, R.H. Miller, and D.R. Keeney (eds.). Methods of soil analysis. part 2: Chemical and microbiological properties. 2nd ed. Amer. Soc. Agron.-Soil Sci. Soc. Amer., Madison, Wis.

Marconi, D.J. and P.V. Nelson. 1984. Leaching of applied phosphorus in container media. Scientia Hort. 22:275-285.

McBride, M.B. 1994. Environmental chemistry of soils. Oxford Univ. Press, New York.

Mills, H.A. and J.B. Jones, Jr. 1996. Plant analysis handbook II: A practical sampling, preparation, analysis, and interpretation guide. Micro-Macro Publishing, Athens, Ga.

Nelson, P.V. 1998. Greenhouse operation and management. 5th ed. Prentice Hall, Upper Saddle River, N.J.

Niedziela,C.E. andP.V.Nelson. 1992. Arapidmethod fordetermining physical properties of undisturbed substrate. HortScience 27:1279:1280.

Nishimoto, R.K., R.L. Fox, and P.E. Parvin. 1975. External and internal phosphaterequirements of field-grownchrysanthemums. HortScience 10:279_ 280.

Olsen, S.R. and L.E. Sommers. 1982. Phosphorus, p. 403-430. In: A.L. Page, R.H.Miller, andD.R. Keeney(eds.). Methods of soil analysis.part2:Chemical and microbiological properties. 2nd ed. Amer. Soc. Agron.-Soil Sci. Soc. Amer., Madison, Wis.

Sposito, G. 1989. The chemistry of soils. Oxford Univ. Press, New York.

Warren, S.L. and T.E. Bilderback. 1992. Arcillite: Effect on chemical and physical properties of pine bark substrate and plant growth. J. Environ. Hort. 10:63-69.

Williams, K.A., P.V. Nelson, and D. Hesterberg. 2000. Phosphate and potassiumretentionandreleaseduring chrysanthemumproduction fromprecharged materials: I. Alumina. J. Amer. Soc. Hort. Sci. 125(6):748-756.

Table 7. Average proportion of added P recovered in the leachate in 'Sunny Mandalay' chrysanthemums, or estimated to remain in pots from treatments with precharged attapulgite, arcillite, or brick chips comprising $20 \%$ or $30 \%$ of the medium (v/v), and a peat-based control medium (Expt. 2).

\begin{tabular}{|c|c|c|c|c|c|c|}
\hline \multirow[b]{3}{*}{ Source } & \multirow{3}{*}{$\begin{array}{l}\text { Mix } \\
(\%)\end{array}$} & \multirow{3}{*}{$\begin{array}{c}\text { Total P } \\
\text { applied } \\
\text { (mg/pot) }\end{array}$} & \multirow[b]{2}{*}{ Leachate } & \multicolumn{2}{|c|}{ Plants } & \multirow[b]{2}{*}{$\begin{array}{c}\text { Estimated } \mathrm{P} \\
\text { remaining in pot }\end{array}$} \\
\hline & & & & Shoots & $\begin{array}{c}\text { Estimated } \\
\text { roots }^{\mathrm{z}}\end{array}$ & \\
\hline & & & & \multicolumn{2}{|c|}{$(\%)$} & \\
\hline \multicolumn{7}{|l|}{ Control medium } \\
\hline \multirow{2}{*}{\multicolumn{2}{|c|}{ Complete fertilizer ${ }^{\mathrm{x}}$}} & & 36.5 & 45.0 & 11.2 & 7.2 \\
\hline & & (280.9) & $(102.6)^{\mathrm{w}}$ & $(126.5)$ & $(31.6)$ & $(20.1)$ \\
\hline -P fertilizer & & $(0)$ & & $(2.8)$ & $(0.7)$ & \\
\hline \multicolumn{7}{|c|}{ Precharged clays, $-\mathrm{P}$ fertilizer } \\
\hline \multirow[t]{2}{*}{ Attapulgite } & 20 & & 5.9 & 12.1 & 3.0 & 78.9 \\
\hline & & $(612.7)$ & $(36.1)$ & $(74.4)$ & $(18.6)$ & $(483.6)$ \\
\hline \multirow[t]{2}{*}{ Arcillite } & 20 & & 18.4 & 43.4 & 10.9 & 29.0 \\
\hline & & $(116.8)$ & $(21.6)$ & $(50.7)$ & $(12.7)$ & $(33.9)$ \\
\hline \multirow[t]{2}{*}{ Brick chips } & 30 & & 10.5 & 26.0 & 6.5 & 57.0 \\
\hline & & $(119.2)$ & $(12.5)$ & $(31.0)$ & (7.7) & $(68.0)$ \\
\hline $\operatorname{LSD}_{0.05}{ }^{\mathrm{v}}$ & & & 7.6 & 3.8 & 1.0 & 7.2 \\
\hline
\end{tabular}

${ }^{\mathrm{Z}}$ Liberal estimation of $\mathrm{P}$ in roots was calculated by assuming that root mass was $25 \%$ of the shoot dry weight and P concentration in roots was the same as in shoot.

${ }^{y}$ Calculated by subtracting $\mathrm{P}$ recovered in plants and leachate from the total applied.

${ }^{\mathrm{x}}$ Complete control.

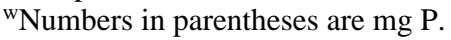

${ }^{v}$ LSD calculated for percentage values. 